\title{
PSYCHOLOGICAL ACCOMPANIMENT OF RULES OF TRAVELLING MOTION STUDYING BY STUDENTS TAKING INDIVIDUAL FEATURES
}

Важливим колом практичних завдань у сфері керування водієм автотранспортом є підвищення ефрективності, результативності та якості діяльності. Вирішення цієї проблеми неможливе без якісної професійної та психологічної підготовки кандидатів у водії, що забезпечує їхню безпечну, безаварійну поведінку на дорозі. Психологічний аспект проблеми підготовки водіїв транспортних засобів має велике значення, оскільки впливає на загальне становлення правильної індивідуальної поведінки в середовищі руху. у практичному аспекті спеціальна психологічна підготовка майбутніх водіїв передбачає, по-перше, оволодіння певною сумою знань, що сприяють психологічній готовності до зустрічі з можливими небезпеками, а також формування на цій основі раціонального ставлення до них; по-друге, набуття навичок управління власним емоційним станом і зниження рівня нервової напруги, тобто оволодіння методами емоційно-вольової саморегуляції. Психологічний супровід процесу вивчення правил дорожнього руху та підготовки майбутніх водіїв загалом з урахуванням індивідуальних особливостей передбачає оволодіння знаннями і практичними вміннями в межах таких п'яти блоків: індивідуальні особливості водія та етичні засади діяльності; пізнавальні фрункції, системи сприйняття і психомоторні навички; емоційні стани та профрілактика конорліктів; основи саморегуляції психічних станів у процесі управління транспортним засобом; психологічна підготовка до здачі іспиту. Окрім засвоєння теоретичних блоків знань, у статті актуалізовано необхідність ідеомоторного тренування, різних тренажерів, стендів та інтерактивної дошки.

Встановлено, що психологічний супровід процесу вивчення правил дорожнього руху та підготовки майбутніх водіїв з урахуванням індивідуальних особливостей забезпечує отримання уявлення щодо пізнавальних функцій та їхнього значення в управлінні транспортним засобом; оволодіння мистецтвом саморегуляції, стійкості до стресових ситуацій на дорозі; навчання методикам, що сприяють підвищенню активності реакцій, зниженню психоемоційної напруги, зняттю втоми.
Ключові слова: психологічний супровід, правила дорожнього руху, кандидати у водіі, психофрізіологічні особливості, психофрізичні стани.

An important range of practical tasks in the field of driving motor vehicles is to increase the efficiency and quality of their activities. The solution to this problem is impossible without high-quality professional and psychological training of candidates for drivers, which ensures their safe, accident-free behavior on the road. The psychological aspect of the problem of driver training is important because it affects the overall formation of correct individual behavior in the traffic environment.

In practice, special psychological training of future drivers involves, first, the acquisition of certain knowledge that contributes to the psychological readiness to meet possible dangers and the formation of a rational attitude towards them on this basis; second, the acquisition of skills to manage their emotional state and reduce the level of nervous tension, that is mastering the methods of emotional and volitional self-regulation. Psychological support of the process of studying road traffic regulations and training future drivers in general, taking into account individual characteristics involves the acquisition of knowledge and practical skills within 5 blocks: individual characteristics of the driver and ethical principles of activity; cognitive functions, systems of perception and psychomotor skills; emotional states and conflict prevention; basics of self-regulation of mental states in the process of driving a vehicle; psychological preparation for the exam. In addition to mastering the theoretical blocks of knowledge, the article highlights the need for ideomotor training, various simulators, stands and an interactive whiteboard.

It is established that the psychological support of the process of studying traffic regulations and training of future drivers, taking into account individual characteristics, provides an idea of cognitive functions and their importance in driving; mastering the art of self-regulation, resistance to stressful situations on the road; learning techniques that help increase the activity of reactions, reduce psycho-emotional stress, relieve fatigue. Key words: psychological support, road traffic regulations, candidates for drivers, psychophysiological features, psychophysical states.
Постановка проблеми. У сучасній науковій літературі з'являється все більше досліджень, якітієючи іншоюмірою стосуються різнихаспектів поведінки людини, пов'язані 3 управлінням автотранспортним засобом, проблемами безпеки в умовах дорожнього руху, вибором оптимальної стратегії безаварійного водіння. Учасниками дорожнього руху є мільйони водіїв, кожен з яких володіє певними психофізіологічними характеристиками, станом здоров'я, особистісними якостями, знаннями, навичками, досвідом, інтересом до водійської діяльності і рівнем мотивації. Водночас на дорогах зустрічається значна кількість непрофесійних водіїв і водіїв-новачків, особистісні якості яких не завжди забезпечують безпечний режим руху. 
У межах вітчизняної психології такі дослідження прийнято пов'язувати передусім із транспортною психологією. Так, прерогативами досліджень цієї галузі традиційно є такі:

1) психофізіологічні характеристики водіїв автотранспортних засобів, що впливають на безпеку на дорозі;

2) особливості протікання психологічних процесів в керуванні автотранспортним засобом (концентрація і розподіл уваги, стомлюваність, здатність до просторової орієнтації);

3) основи психофізіології діяльності водіїв та їхньої психологічної надійності в системі «водій - автомобіль - дорога - середовище» [1, с. 95].

Аналіз останніх досліджень і публікацій. Вітчизняні психологи відзначають, що кандидати у водії повинні володіти низкою психофізіологічних і психічних функцій, що характеризуються певною умовою розвитку (Г. Ложкін, Н. Повякель [3]). Вони повинні сприймати значну кількість інформації щодо характеру й режиму руху всіх його учасників, параметрів дороги, довкілля, засобів регулювання, стану вузлів та агрегатів автомобіля (за допомогою різних приладів) тощо. Отже, водій має не лише сприймати великий потік інформації, але й здійснювати ї̈ переробку (аналіз) і приймати відповідне швидке рішення в умовах обмеженого часу. Часто саме дефіцит часу є причиною дорожньо-транспортних пригод. Окреслимо невеликий список помилок, пов'язаних із дефіцитом часу. Отже, ними є помилки в проведенні ситуаційного аналізу (наприклад, наближуючись до перехрестя, водій вважає, що жовтий сигнал світлофора зміниться зеленим, але вмикається червоний); неправильне прийняття рішення (наприклад, замість маневру, єдино необхідного в певній дорожньо-транспортній ситуації, водій застосовує екстрене гальмування); помилковість дії (наприклад, прийнято правильне рішення застосувати екстрене гальмування, однак замість того, щоб натиснути на педаль гальма, водій помилково натискає на педаль акселератора, тим самим збільшує швидкість). Можемо стверджувати, що надійність роботи водіїв під час керування автомобілем значною мірою залежить від їхніх психофізіологічних особливостей.

Однак, незважаючи на актуальність дослідження, досі немає загальноприйнятого методу дослідження й прогнозування безаварійного керування автотранспортом. Вже не викликає сумніву той факт, що безаварійність керування автотранспортом пов'язана з певними психофізіологічними якостями водія, однак зведення його лише до дослідження психофізіологічних параметрів, на нашу думку, $€$ досить вузьким і неповним.

Як свідчить вітчизняна статистика за 2019 рік, більшість дорожньо-транспортних пригод (ДТП) в нашій країні (близько 80\%) відбувається через необачність водіїв, тоді як зовнішні умови, що впливають на безпеку дорожнього руху, як правило, в момент скоєння дорожньо-транспортних пригод сприятливі. Так, 57\% ДТП сталися за ясної погоди, $59 \%$ - у світлий час доби, 62\% - в умовах сухої проїжджої частини, 87\% - під час руху транспортних засобів прямою ділянкою дорожнього полотна. Наїзд на пішохода найчастіше зустрічається серед усіх інших видів ДТП, становлячи трохи менше половини від загальної кількості всіх скоєних на території України дорожньо-транспортних пригод [10]. Такий високий рівень аварійності на дорогах, що вийшов 3-під контролю, свідчить про те, що наявна система профілактики ДТП себе вичерпала й сьогодні демонструє повну неспроможність.

Отже, вже є достатньо визначене підтвердження того, що причини високої аварійності слід шукати не лише в незадовільних психофізіологічних показниках, але й у станах, що формують їх. Статистика свідчить про те, що роль людського чинника в аварійності з роками зростає, тоді як технічного - знижується, і якщо вивчати сутність помилок, то можна помітити, що їх більшість має психологічну природу [5, с. 11]. Варто також відзначити повторюваність ДТП і порушень Правил дорожнього руху (ПДР) у одних і тих же водіїв за відносної благополучності умов руху. Професійне навчання й тренування також не можуть гарантувати відсутність ДТП. Таким чином, психічний стан водіїв $є$ ключовим чинником безпеки на дорогах. Причому не окремо взяті його складники (концентрація уваги або втома), а всі компоненти психічного стану в їхньому взаємозв'язку і взаємодії.

Вирішення окреслених завдань неможливе без якісної професійної і психологічної підготовки кандидатів у водії під час вивчення ПДР та підготовки до керування автомобілем загалом, що забезпечує їхню безпечну, безаварійну поведінку на дорогах. На жаль, нині підготовка майбутніх водіїв здійснюється без урахування індивідуальних психологічних якостей, що досить неефективно і не відповідає сучасним вимогам. Саме заклади освіти $€$ ключовою ланкою системи «людина - автомобіль - дорога». Їхня роль у забезпеченні безпеки дорожнього руху є вирішальною.

Постановка завдання. 3 огляду на актуальність проблеми та їі прикладне значення виникла необхідність здійснення психологічного супроводу процесу вивчення ПДР та підготовки до керування автомобілем загалом. Отже, мета статті полягає у відображенні процесу психологічного супроводу як цілеспрямованого формування психічних властивостей майбутніх водіїв, які необхідні для надійного й безпечного керування автомобілем у будьяких дорожніх умовах. 
Виклад основного матеріалу дослідження. Процес керування автомобілем $\epsilon$ складною роботою, яка здійснюється в умовах високих психоемоційних перевантажень, характеризується значним обсягом інформації, що переробляється, необхідністю прийняття рішень в обмеженому часі, тобто $€$ напруженою діяльністю з високою небезпекою і відповідальністю [9, с. 355]. Така специфіка висуває найвищі вимоги до психофізіологічних якостей кандидатів у водії, тому їхню підготовку необхідно здійснювати на професійному рівні, з урахуванням індивідуальних психофізіологічних особливостей.

Навмисне невиконання ПДР, на думку С. Осташевського, пояснюється тим, що між знаннями правил та їхнім виконанням знаходяться внутрішні (психічні) механізми, що регулюють діяльність водіїв. Найчастіше водії, які схильні до аварійного типу водіння, не підозрюють про це, «не бачать себе з боку», вважають, що поведінка на дорозі і в суспільстві абсолютно не залежать одна від одної. Для кандидатів у водії необхідно в період навчання розкрити ті внутрішні (психічні) механізми регуляції поведінки, які потім утворюють їхній стиль водіння [6, с. 17].

Отже, водій має знати свої фізіологічні та психологічні особливості, щоб уміти вчасно застосувати їх з урахуванням змін, що виникають в організмі. Окрім того, він повинен знати власні можливості в керуванні автомобілем і ті якості, які лежать в основі його майстерності й безпеки руху. Для безпечного керування автомобілем найважливішими психічними властивостями є відчуття, сприйняття, увага, мислення, пам'ять, емоції і воля [11, с. 147]. Перебуваючи за кермом, водій утримує в полі зору дорогу, бачить перешкоди на ній, пішоходів, транспортні засоби, стежить за показниками приладів, на слух контролює роботу двигуна, отримує інформацію щодо правильності виконуваних дій з керування автомобілем тощо. Всі ці відомості $€$ результатом відчуттів, тобто відображення у свідомості окремих властивостей і якостей предметів та явищ матеріального світу, безпосередньо діючих на органи чуття.

У практичному аспекті вивчення ПДР та спеціальнапідготовка майбутніхводіїв в умовахпсихологічного супроводу передбачають, по-перше, оволодіння певною сумою знань, що сприяють психологічній готовності до зустрічі з можливими небезпеками, й формування на цій основі раціонального ставлення до них; по-друге, набуття навичок управління власним емоційним станом і зниження рівня нервової напруги, тобто оволодіння методами емоційно-вольової саморегуляції. 3 огляду на це значну увагу в психологічному супроводі слід приділяти психологічним тренінгам, у межах яких практично опрацьовуються методи саморегуляції.
Основними завданнями психологічного супроводу процесу вивчення правил дорожнього руху та підготовки майбутніх водіїв визначено такі:

1) сприяння формуванню безпечного й ефективного керування транспортним засобом у різних умовах руху;

2) набуття практичного досвіду оцінки власного психічного стану й поведінки шляхом навчання прийомам психологічної саморегуляції, що дає змогу залишатися спокійним і впевненим у будь-якій дорожній ситуації;

3) створеннявнутрішньоїпсихологічноїустановки на отримання задоволення від безпечного, культурного водіння, ефективного використання автомобіля, ввічливого, тактовного ставлення до інших учасників дорожнього руху;

4) здійснення психологічної підготовки до здачі іспиту в МВС України.

Технократичний підхід до процесу вивчення ПДР та підготовки майбутніх водіїв спричинив формальний виклад (або лише на теоретичному рівні) надзвичайно важливих розділів «Професійна надійність водіїв» і «Психофізіологічні та психічні якості водіїв» освітньої програми. Однак, на нашу думку, в цих розділах необхідно зробити акцент на практичній роботі, яка дасть змогу кожному кандидату у водії визначити відповідність власних психологічних і особистісних якостей вимогам водійської діяльності.

На основі цих рекомендацій практичне вивчення ПДР та підготовка майбутніх водіїв загалом мають будуватися за такими двома стратегіями:

- навчання кандидатів у водії із сильною мобільною нервовою системою має спрямовуватися на розвиток здібностей до маневрування, швидкісного керування тощо;

- для водіїв зі слабкою або інертною нервовою системою підготовка полягає в тому, що вона має компенсуючий характер (розвиваються і тренуються ті здібності, які від природи розвинені слабо й можуть спричинити несприятливі наслідки в дорожній ситуації).

У межах вивчення ПДР та підготовки загалом необхідно звертати увагу кандидатів у водії на неусвідомлювані майбутні проблеми. Багато хто з них навіть не розуміє, що бере на себе величезну відповідальність, керуючи джерелом підвищеної небезпеки (Т. Марценюк, К. Бойко [4, с. 36]). Ще одним значущим моментом у підготовці майбутніх водіїв $€$ питання психофізіології майбутнього водія на основі тестів на психомоторну реакцію, бічний зір, здатність до швидкого розподілу й переключення уваги з одночасним паралельним розглядом питань психології безпечного водіння (В. Щлеґ та Дж. Щейд [12, с. 14]). Наприклад, тест на здатність до швидкого розподілу й переключення уваги варто виконати 
два рази. Перший раз він виконується за звичайною методикою, другий - з імітацією розмови по мобільному телефону. У таких умовах кандидати у водії отримують наочне уявлення про негативний вплив розмови по телефону на безпеку дорожнього руху.

Далі психологічний супровід процесу вивчення ПДР та підготовки до керування автомобілем майбутніх водіїв передбачає обговорення того, які властивості психічних пізнавальних процесів (відчуття, сприйняття, уваги, мислення, пам'яті) особливо сильно впливають на керування автомобілем. Важливим моментом є визначення за допомогою тестових методик (шкала ситуативної та особистісної тривожності; методика диференційованої самооцінки функціонального стану; методика оцінки нервово-психічної стійкості «Прогноз»; тест Вартегга) індивідуальних відмінностей цих властивостей для конкретного кандидата у водії. На підставі цього викладач має змогу розробити рекомендації для кандидатів у водії стосовно розвитку певних якостей та навичок, які забезпечують ефективну орієнтацію в дорожній обстановці.

Наступним важливим моментом підготовки майбутніх водіїв $є$ розгляд психологічних аспектів керування автомобілем кандидатів у водії як операторів системи «водій - автомобіль - дорога - середовище» [8, с. 8]; аналіз причини зневажливого ставлення водіїв до заходів щодо забезпечення безпеки за кермом; формування поняття про культуру дорожнього руху, правила ввічливої поведінки стосовно інших учасників дорожнього руху.

Психологічний супровід процесу вивчення правил дорожнього руху та підготовки майбутніх водіїв з урахуванням індивідуальних особливостей передбачає оволодіння знаннями й практичними вміннями в межах 5 таких блоків:

- індивідуальні особливості водія та етичні засади діяльності;

- пізнавальні функції, системи сприйняття й психомоторні навички;

- емоційні стани та профілактика конфліктів;

- основи саморегуляції психічних станів у процесі управління транспортним засобом;

- психологічна підготовка до здачі іспиту.

Розглянемо детальніше кожен з блоків. Так, блок пізнавальних функцій, систем сприйняття і психомоторних навичок передбачає оволодіння поняттям про пізнавальні функції (увага, сприйняття, пам'ять, мислення); засвоєння причин відволікання уваги під час керування транспортним засобом; формування здатності зберігати увагу за наявності відволікаючих чинників; усвідомлення впливу втоми й сонливості на властивості уваги; вибір необхідної інформації в процесі керування транспортним засобом; системи сприйняття та їхнє значення в діяльності водія; небезпеки, пов'я- зані з неправильним сприйняттям дорожньої обстановки; поле зору, гостроту зору й зону видимості; периферичний і центральний зір; чинники, що впливають на зменшення поля зору водія; інші системи сприйняття (слухові, вестибулярні, суглобово-м'язові відчуття, інтероцепція) та їхнє значення в діяльності водія; вплив швидкості руху транспортного засобу, алкоголю, медикаментів та емоційних станів водія на сприйняття дорожньої обстановки; навички розпізнавання небезпечних ситуацій; прийняття рішення в різних дорожніх ситуаціях; значущість прийняття правильного рішення на дорозі; формування психомоторних навичок керування автомобілем; вплив вікових та гендерних відмінностей на формування психомоторних навичок; просту й складну сенсомоторні реакції, реакцію в небезпечній зоні; чинники, що впливають на швидкість реакції [13, с. 256].

Блок етичних засад діяльності водія передбачає засвоєння знань щодо цілей навчання керуванню транспортним засобом; мотивації в житті і на дорозі; схильності до ризикованої поведінки на дорозі; цінностей людини, групи і водія; впливу реклами, преси та кіноіндустрії на поведінку водія; помилкового відчуття безпеки; впливу соціальної ролі і соціального оточення на стиль водіння; способів нейтралізації соціального тиску в процесі керування транспортним засобом; етичних норм водія; відповідальності водія за безпеку на дорозі; взаємин водія з іншими учасниками дорожнього руху; вразливих учасників дорожнього руху, які потребують особливої уваги (пішоходи, велосипедисти, діти, люди похилого віку, інваліди); причин віддання переваги на дорозі транспортним засобам, обладнаним спеціальними світловими й звуковими сигналами; особливостей поведінки водіїв і пішоходів в житлових зонах і в місцях паркування.

Блок основ ефективного спілкування має такі складові частини: поняття «спілкування», його функції, етапи спілкування; характеристика вербальних та невербальних засобів спілкування; основні «ефекти» у сприйнятті інших людей; стилі спілкування; бар'єри в міжособистісному спілкуванні, причини та умови їхнього формування; особливості спілкування в умовах конфлікту; правила, що підвищують ефективність спілкування.

Блок емоційних станів та профілактики конфліктів має такі складові частини: емоції і поведінка водія; емоційні стани (гнів, тривога, страх, ейфорія, стрес, фрустрація); зміна сприйняття дорожньої ситуації і поведінки в різних емоційних станах; управління поведінкою на дорозі; екстрені заходи реагування; способи саморегуляції емоційних станів; конфліктні ситуації і конфлікти на дорозі; причини агресії і ворожості у водіїв та інших учасників 
дорожнього руху; тип мислення, що спричиняє агресивну поведінку; зміна поведінки водія після вживання алкоголю й медикаментів; вплив самопочуття на поведінку водія; профілактика конфліктів; правила взаємодії з агресивним водієм.

Блок саморегуляції і профілактики конфліктів має такі складові частини: набуття практичного досвіду оцінки власного психічного стану й поведінки, досвіду саморегуляції, а також первинних навичок профілактики конфліктів; вирішення ситуаційних завдань щодо оцінки психічного стану, поведінки, профілактики конфліктів і спілкування в умовах конфлікту; психологічний практикум.

Після засвоєння окреслених блоків знань актуалізується необхідність ідеомоторного тренування. Ідеомоторне тренування - це планомірно повторюване, свідоме, активне уявлення й відчуття навички, що засвоюється [2, с. 47]. Ідеомоторне тренування може застосовуватися на всіх етапах підготовки кандидатів у водії. У проведенні аутогенних тренувань формується звичка позитивного мислення учасників дорожнього руху, їхній настрій на спокійне, врівноважене та уважне водіння. Ці тренування дають змогу зняти емоційні навантаження, до яких схильні водії на дорозі. Ідеомоторні тренінги полягають в уявному виконанні водієм дій, пов'язаних з водінням автомобіля. Завдяки властивостям людської психіки це дає змогу закріпити вже наявні навички водіння, а також удосконалювати їх [7, с. 71]. Окрім того, такі тренування добре позначаються на мисленні і пам'яті, швидкості реакцій, а також інших якостях, необхідних для безпечного водіння транспортних засобів; сприяють формуванню вмінь надовго концентруватися на дорожній обстановці, швидко реагувати на її зміну. Кандидати у водії, що пройшли психологічну підготовку, здатні швидко приймати правильні рішення на дорозі, які в подальшому сприятимуть уникненню дорожньо-транспортних пригод. Окреслені навички досягаються в поєднанні з використанням різних тренажерів, стендів та інтерактивної дошки. Це відбувається завдяки моделюванню на цих тренажерах ситуацій, максимально наближених до реальності.

Отже, психологічний супровід процесу вивчення ПДР та підготовки до керування автомобілем майбутніх водіїв дає змогу отримати уявлення щодо пізнавальних функцій та їхнього значення в керуванні транспортним засобом; оволодіти мистецтвом саморегуляції, стійкості до стресових ситуацій, корекції своєї поведінки в конфлікті; навчитися методикам, що сприяють підвищенню активності реакцій, зниженню психоемоційної напруги, зняттю втоми.

Висновки 3 проведеного дослідження. Таким чином, психологічний супровід процесу вивчення правил дорожнього руху та підготовки майбутніх водіїв сприяє інноваційному підходу до організації підготовки водіїв. У її межах передбачаються врахування індивідуальних психологічних відмінностей між кандидатами у водії, психологічна корекція професійно-значущих якостей і спостереження за рівнем їхнього розвитку в динаміці. Це дає змогу здійснювати прогноз ефективності та безаварійності водійської діяльності та забезпечувати безпеку дорожнього руху на сучасному рівні. Психологічний супровід процесувивченняправилдорожнього рухутапідготовки майбутніх водіїв з урахуванням індивідуальних особливостей має прикладне значення й може застосовуватися в освітньому процесі автошкіл, професійно-психологічному відборі, у визначенні професійної придатності водіїв.

\section{ЛIТЕРАТУРА:}

1. Гайдукевич В., Потийчук О. Основи транспортної психології. Рівне : НУВГП, 2012. 208 с.

2. Клінковштейн Г., Афранасьєв М. Організація дорожнього руху : підручник для вузів. 5-те вид., перераб. і доп. Москва: Транспорт, 2011. 247 с.

3. Ложкин Г., Повякель Н. Практическая психология в системах «человек - техника» : учебное пособие. Киев : МАУП, 2003. 296 с.

4. Марценюк Т.., Бойко К. Водіння автомобіля і гендерні стереотипи: міфи та реальність про жінок за кермом у контексті глобальних змін. Ґендерний журнал «Я». Серія: Ґендер і глобалізація. 2013. № 2 (33). C. 35-38.

5. Назаркін О., Сазонов О. Підготовка до прийняття самостійних рішень в оперативних нестандартних ситуаціях при водінні автомобіля. Методична розробка 3 дисципліни «Автомобільна підготовка». Харків: НУВС, 2015. 25 с.

6. Осташевський С. Надійність водія та основні фрактори, що її визначають. Автошляховик України. 2013. Вип. 1. С. 17-19.

7. Мацегора Я.В., Приходько І.І., Полторак С.Т. та ін. Психологічна підготовка водіїв внутрішніх військ МВС України до керування транспортним засобом в екстремальних умовах діяльності : навчальний посібник. Харква : Академія ВВ МВС України, 2013. 127 с.

8. Радченко К. Психологічні особливості створення гендерних стереотипів засобами масової інфоормації : автореф. дис. ... канд. психол. наук:спец. 19.00.05; НАПНУкраїни, Інститутпсихології ім. Г.С. Костюка. Київ, 2014. 20 с.

9. Савицька В. Психологічний супровід профресійного навчання як умова фрормування психологічної готовності до професійної діяльності. Проблеми сучасної психології. 2019. Вип. 4. С. 353-360.

10. Статистика ДТП в Україні. URL: http://patrol. police.gov.ua/statystyka (дата звернення: 12.12. 2020).

11. Rothengatter T., Huguenin R.D. Traffic and Transport Psychology. 1sted. UK : Elsevier Science, 2004. 518p.

12. Schlag B., Schade J. Traffic and transportation psychology. Cheltenham : Edward Elgar Publishers, 2010. 125 p.

13. Underwood G. Traffic and Transport Psychology: Theory and Application Hardcover. Oxford : Elsevier Science, 2015. 656 p. 